\title{
Merkel Cell Polyomavirus T Antigen Positive
}

National Cancer Institute

\section{Source}

National Cancer Institute. Merkel Cell Polyomavirus T Antigen Positive. NCI Thesaurus.

Code C142093.

An indication that the expression of the Merkel cell polyomavirus T antigen has been detected in a sample. 